\title{
Evaluation of coursework information access and sharing on smart devices by postgraduate students
}

\section{Authors:}

Elelwang J. Dhlamini ${ }^{1}$ (D)

Martie A. Mearns ${ }^{1}$ (D)

Affiliations:

${ }^{1}$ Department of Information and Knowledge

Management, University of

Johannesburg, Johannesburg,

South Africa

Corresponding author:

Elelwang Dhlamini,

edhlamini13@gmail.com

\section{Dates:}

Received: 10 Apr. 2018

Accepted: 08 Nov. 2018

Published: 28 Mar. 2019

How to cite this article: Dhlamini, E.J. \& Mearns, M.A., 2019, 'Evaluation of coursework information access and sharing on smart devices by postgraduate students', South African Journal of Information Management 21(1), a991. https://doi.org/10.4102/ sajim.v21i1.991

\section{Copyright:}

(C) 2019. The Authors. Licensee: AOSIS. This work is licensed under the Creative Commons Attribution License.

\section{Read online:}

Scan this QR
code with your
smart phone or
mobile device
to read online.

Background: There is a growing trend for students to use their smart devices to share coursework information and access social media platforms. Although smart devices have been in existence and used by the students for several years, very little has been documented on the coursework information accessed and shared on smart devices.

Objectives: The study focused on investigating academic activities in terms of students' coursework information accessing and sharing, which include the type of information they use their smart devices for and the frequency of using their smart devices to access coursework information and sources of information. The study also identified challenges that students come across while accessing and sharing coursework information.

Method: The mixed-method sequential research approach was used to collect data using questionnaires and interviews. The quantitative phase involved the collection and analysis of data using questionnaires. Questionnaires were sent online to the entire population of 255 students who had completed their workshops and were not on campus any more, as well as a paper format questionnaire that was handed out to the $60 \mathrm{MCom}$ first-year students who were still attending their workshops on campus. A total of 315 questionnaires were sent to the students. There were 61 online questionnaires and 51 paper questionnaires returned. Therefore, a total of 112 questionnaires were returned. The qualitative phase involved the collection and analysis of data using interviews with 10 participants.

Results: The results revealed that students used their smart devices for accessing and sharing coursework activities such as announcements, handouts, lecture notes and articles. Bibliographic references, group discussion notes, online articles and book lists were accessed and shared frequently by participants. Students used their smart devices frequently to access sources of information such as Blackboard, academic databases and Google Scholar.

Conclusion: The implications and contributions of the study are that although students use their smart devices regularly, there is a need for institutions to understand the type of information that is gathered and shared using smart devices. As students also access social media platforms they need to understand the implications of relevant policies.

\section{Introduction}

With the advancement of mobile technology, smart devices have been introduced to enable users to access, process and share information quicker. Although mobile technology includes cell phones, laptops and tablets, this study focuses on tablets and smartphones as popular devices used by tertiary students. A smartphone is defined as a programmable mobile phone with advanced capabilities and features that assists users in their day-to-day life (Ting et al. 2011:193).

Tablets are portable computing devices that are larger than smartphones. Like most new smartphones, tablets use a touch screen as the primary method of interaction. According to Mayisela (2013:1), tablets and smartphones are the latest explosion in the field of technology development and they are affordable.

Given the increasing rate of technological advancement, the use of smart devices in information gathering and sharing has become significant. An understanding of what information students gather and share with their smart devices is crucial for institutions of higher learning. Institutions can facilitate the required information technology support to the students when they can identify specific information that students access and share on their smart devices. 
For the purpose of this study, the term 'smart device' is used to include both smartphones and tablets. There are quite a number of emerging studies on smart devices, as is evident in Balakrishnan and Loo (2012); Cummings, Merrill and Borrelli (2010); Kafyulilo (2014); and Keengwe and Bhargava (2013). However, most of the studies have concentrated on the perception of the tertiary or higher education institutions (HEIs) on the provision of information systems, particularly virtual leaning environments (VLEs) such as Blackboard, that can be accessed online by students using devices such as cell phones, tablets and laptops.

The significance of this research is to extend the knowledge base and the understanding of the information activities of tertiary students by focussing on the (1) type of information they use their smart devices for, (2) information that is most likely to be frequently shared, (3) frequency of using smart devices to access sources of information as well as (4) challenges that students are likely to come across while accessing and sharing information on their mobile devices. Such knowledge can assist tertiary institutions to incorporate educational technologies and improved VLEs that are compatible with the evolvement of how tertiary students use their smart devices.

This research article has already presented a short overview of existing work on the information activities of students. The section that follows covers the literature review and the methodology approach that was employed in the study. The results and findings are analysed and then discussed, followed by recommendations for future studies and conclusions in the final section.

\section{Literature review}

Previous studies, including Hlodan (2010), Sheng, Siau and Nah (2010) and Mayisela (2013), have not really concentrated in detail on the use of smart devices in information activities among students but have largely concentrated on improving teaching and learning. Some studies focus on the ability of institutions to provide real-time information through advanced technology (Mang \& Wardley 2012:303).

Smartphones have become popular and are in demand because of the functions they offer to users. Suki (2013:124) has expanded the definition of a smartphone to include 'advanced computing ability and connectivity that comprises of functions such as portable media, camera and navigation system'. These functions can be manipulated by users to share information such as emails, photos and documents. Kafyulilo (2014:117) elaborated further that studies conducted in the UK have indicated that students enjoy learning opportunities provided by mobile devices through their portability and Internet access. These opportunities enable students to search and send information to each other while they are on the move. They are no longer confined to location, time and the specific way that information can be gathered.

Shin (2012:563) believes that smartphones are gradually outnumbering other forms of computing. This means that students are now opting to use their smartphones or tablets instead of carrying around their laptops or having to be confined to a specific space to use their desktop computers. Although the tablet is a relatively new product in the development of mobile devices, with the first version released in 2010, it has now become a subject of studies in higher education (Manuguerra \& Petocz 2011:61).

There is also a research focus on how institutions align their systems with appropriate technology for teaching and learning. Authors who have conducted research in this area include the following: Whittaker and Dunham (2009), Idrus and Ismail (2010), Parsons (2010), Sheng et al. (2010), Krogstie (2011), Manuguerra and Petocz (2011), Menkhoff and Bengtsson (2012), Taleb and Sohrabi (2012), Magnuson (2013) and García-Peñalvo and Conde (2015). According to a study conducted by Dresselhaus and Shrode (2012) at the Utah State University, library systems such as catalogues, journals and databases are continuously improved to enable students to access resources for their course information. Virtual learning environments such as Blackboard, for instance, are used to give students access to academic information such as registered modules, announcements, timetable, financial statements, assessment submission and results. In light of trends towards extensive use of smart devices, it is essential for libraries to provide access to their collections and services in ways that are compatible with mobile devices (Dresselhaus \& Shrode 2012:96).

Roux and Falgoust (2013:5) have noted what is termed 'side effects' instead of 'disadvantages'. The authors established that many mobile device users carry with them a great degree of private information like contact lists, browser history and a record of recent activities. In the cases where authorities need access to mobile devices for legal purposes, users may feel violated when certain information becomes public. If students are not aware of the nature of exposure when sharing and accessing information, they might experience identity theft problems. For example, when students access and share information online, their location links and contact details can be accessed by fraudsters as they hack into their online applications. As students use online discussion forums to share information, their privacy and security of information can be compromised.

\section{Research methodology}

The study applied a mixed-method approach, collecting data sequentially through paper-based and online questionnaires as well as face-to-face interviews. The target population was purposely selected from a coursework master's class at a South African HEI. Participants completing the questionnaire and the interviews were students registered for the Master of Commerce (MCom) coursework programme in the Department of Business Management. These students were registered during the period of 2011-2016, making up the total population of the students considered for this study. The reason for this being the population is because of the increased use of mobile devices during this time frame. 
The number of students registered on the course alumni database combined with the current students at the time was 315. All the students who participated in the questionnaires and the interviews were informed of their rights. A consent letter with the explanation of the scope of study and reasons for it was drafted and given to the participants to ensure that they understood what was involved in the process. The questionnaire was adapted from an existing questionnaire developed by Rellinger in 2014, who investigated the diffusion of smartphones and tablets in higher education, comparing the faculty and student perceptions and uses.

The development of the questionnaire and interview questions was done with the assistance of a university statistical consultation service. Selection was based on the possibility of access to the survey instrument as well as demographic data from the departmental information system. A total of 315 MCom students were registered for coursework between 2011 and 2016. All participants had access to the questionnaire through class attendance or via the departmental database of alumni. As part of the quantitative data collection process, students who were registered from 2011 to 2015 were notified of the questionnaire via email as they were no longer attending workshops on campus. A questionnaire was developed using the SurveyMonkey tool and a link was sent to the participants via email. The questionnaire was sent to all 255 students who were registered in 2011-2015. A paper questionnaire was sent to $60 \mathrm{MCom}$ first-year students who were still attending workshops on campus. The number of complete responses from the online questionnaire was 61, while 51 complete paper questionnaire responses were received. A total of 112 complete responses were received, resulting in a $35.5 \%$ response rate.

From the 112 responses, $47.3 \%$ were male responses and $52.7 \%$ were female responses. The participants were asked to select their age group from a choice of five groups (18-24, 25-34, 35-44, 45-54 and 55-64 years). The 25-34 years age group accounted for $47 \%$ and the $35-44$ years age group had $39 \%$ of participants. Therefore, these two groups accounted for most participants. The first phase used a questionnaire that was distributed by hand as well as online to the sample. The participants were provided with a list of items they were likely to access, the frequency of accessing this information, the frequency of using smart devices to access sources of information used as well as the challenges that they were likely to experience. They were then required to use a fivepoint Likert scale to indicate their responses. A score higher than 3 was regarded as very good, while a score below 3 was regarded as not good. The questions were indicated on section D12-D17 of the questionnaire (Appendix 1).

Questions D12 and D15 aimed to establish the information activities that participants performed on their smart devices. Question D12 asked participants how often they used their smart device for accessing and sharing the specific coursework information. Question D15 probed participants to indicate how often they shared the information on their studies from a list provided. Question D16 asked participants to indicate how often they used their smart device to access a list of sources of information for their coursework. Question D17 asked participants to indicate how likely they were to experience certain aspects in the usage of their smart device.

The data were statistically analysed by the Statkon Department using the Statistical Package for the Social Sciences (SPSS) software. The researcher screened the data set for missing data and outliers. Frequency distributions were generated and studied. Irregularities were investigated and corrected if possible prior to using the descriptive statistics method. The descriptive statistics included mean and standard deviation, and scores were produced for all questions.

The second phase used the collection and analysis of data using interviews. The interview participants were selected from among the participants to the questionnaire and they all gave consent to participate in the interview. With the group of students selected for interviews, it was necessary to physically meet with the students and 10 participants were willing to engage in in-depth interviews. The interview sessions of 15-20 min were conducted face-to-face with 10 participants. Question 1.1 (Appendix 2) asked participants to indicate the kind of information they accessed using their smart device while studying towards their MCom degree. The results from the questionnaire were triangulated to the interview results to provide a holistic and in-depth investigation of coursework information accessed and shared by tertiary students on smart devices. All the data that was gathered during interviews was transcribed and analysed using coding and creating categories for abstraction. The interview data was analysed to identify key themes and patterns.

The results of both the questionnaires and interviews were depicted in tables, discussed and compared.

\section{Ethical consideration}

Permission for this study was obtained from the Faculty of Management Ethics Committee at the University of Johannesburg (Clearance number: IKM2018_026) before students could be contacted. All research has been conducted under the guidelines of the Faculty of Management ethical requirements and adhered to the University of Johannesburg ethical policies and procedures.

\section{Results and findings}

The results of the questionnaire and interviews were analysed to establish the kind of coursework information that students accessed on their smart devices, the frequency of accessing the coursework information, the frequency of using smart devices to access sources of information as well as the challenges they faced when accessing coursework information. 


\section{Coursework information accessed and shared on smart devices}

Question D12 in the questionnaire asked participants how often they used their smart devices for accessing and sharing the information related to their coursework. The results from the questionnaire (Appendix 1, Q3) were analysed to establish what coursework information the participants accessed using their smart devices. Table 1 displays the results for the coursework information that students accessed using their smart devices. A higher mean score indicates the type of information that was accessed most by participants.

Item D12.1 (accessing and reading announcements) was rated high with a score of 3.91 while item D12.4 (retrieving coursework images from other students) was rated the lowest with a score of 3.07. This means that participants mostly accessed announcements on their smart devices as compared to other items listed. The overall mean score for Question D12 was 3.4. The interview results (Appendix 2, Q1) indicate that participants used their smart devices to access study material that includes notes, announcements, study guides and books, as indicated in Table 2 .

Responses that had similar meaning regarding the information accessed by students were grouped together into themes. This information includes lecturer notes, announcements, study guides, articles, assignments, books and assessment results from the student portal. From Table 2, it is clear that module announcements were mentioned by $30 \%$ of the participants.

Linked to the usage of smart devices for coursework information activities is the frequency of using smart devices to access the information. Gikas and Grant (2013:21) added that students use their smart devices frequently to access course content such as course readings, discussion boards and any information related to their studies.

\section{The frequency of using smart devices to access and share information}

The items that were listed for the students were the book lists the students used for preparing for classes and assessments, the bibliography or references that they needed

TABLE 1: Descriptive statistics for smart device usage items.

\begin{tabular}{lccc}
\hline Item & $\begin{array}{c}\text { Number of } \\
\text { participants }\end{array}$ & Mean & $\begin{array}{c}\text { Standard } \\
\text { deviation }\end{array}$ \\
\hline $\begin{array}{l}\text { D12.1 Accessing and reading } \\
\text { announcements }\end{array}$ & 100 & 3.91 & 0.965 \\
D12.2 Accessing course assignments & 99 & 3.38 & 1.149 \\
$\begin{array}{l}\text { D12.3 Sharing handouts, lectures, } \\
\text { articles }\end{array}$ & 100 & 3.33 & 1.083 \\
$\begin{array}{l}\text { D12.4 Retrieving coursework images } \\
\text { from other students }\end{array}$ & 100 & 3.07 & 1.200 \\
$\begin{array}{l}\text { D12.5 Sharing notes with other } \\
\text { students }\end{array}$ & 99 & 3.27 & 1.114 \\
$\begin{array}{l}\text { D12.6 Sharing ideas with other } \\
\text { students via group discussions }\end{array}$ & 100 & 3.74 & 1.228 \\
$\begin{array}{l}\text { D12.7 Sharing additional learning } \\
\text { material }\end{array}$ & 100 & 3.48 & 1.105 \\
\hline
\end{tabular}

to research relevant information on coursework, the notes used to prepare for classes, class timetables, coursework information shared on group discussion forums as well as research information specific to the coursework that was available on online articles (Table 3).

Participants rated group discussion forums the highest, with a score of 3.84, as indicated in Table 3. The item bibliographic reference lists was rated the lowest, with a score of 2.86. This means that participants most frequently used their smart devices to access and share information from group discussion forums. Other items such as research information from online sources, class timetables and notes also received ratings above 3 , which is regarded as good as compared to the ratings that were scored below 3. Participants were also asked to indicate how frequently they used their smart devices to access different sources of information from the provided list of items indicated in Table 4.

\section{The frequency of using smart devices to access sources of information}

The sources of information accessed from the results indicate where the students were likely to obtain their coursework

TABLE 2: Interview responses and themes on information accessed on smart devices.

\begin{tabular}{|c|c|c|}
\hline Participant & Responses & Themes \\
\hline Participant 1 & $\begin{array}{l}\text { Lecture notes, module } \\
\text { announcements }\end{array}$ & Study material \\
\hline Participant 2 & $\begin{array}{l}\text { Lecture notes, study guides, } \\
\text { articles, assignments, books }\end{array}$ & $\begin{array}{l}\text { Study material, sources of } \\
\text { information, assessments }\end{array}$ \\
\hline Participant 3 & $\begin{array}{l}\text { Articles, electronic databases, } \\
\text { Google Scholar }\end{array}$ & Sources of information \\
\hline Participant 4 & $\begin{array}{l}\text { Coursework, lecture notes, exam } \\
\text { results, tests, articles }\end{array}$ & Study material, assessments \\
\hline Participant 5 & $\begin{array}{l}\text { Module announcements, } \\
\text { study material }\end{array}$ & Study material \\
\hline Participant 6 & Module announcements, results & Study material, assessments \\
\hline Participant 7 & Assignment results & Assessments \\
\hline Participant 8 & $\begin{array}{l}\text { Databases, submitting chapters } \\
\text { to supervisor }\end{array}$ & $\begin{array}{l}\text { Sources of information, } \\
\text { communication }\end{array}$ \\
\hline Participant 9 & Tests & Assessments \\
\hline Participant 10 & Study material & Study material \\
\hline
\end{tabular}

TABLE 3: Descriptive statistics for coursework information most frequently accessed and shared.

\begin{tabular}{lccc}
\hline Item & $\begin{array}{c}\text { Number of } \\
\text { participants }\end{array}$ & Mean & $\begin{array}{c}\text { Standard } \\
\text { deviation }\end{array}$ \\
\hline D15.1 Book lists & 100 & 3.05 & 1.123 \\
D15.2 Bibliographic reference lists & 100 & 2.86 & 1.146 \\
D15.3 Notes & 100 & 3.51 & 1.105 \\
D15.4 Class timetable & 99 & 3.35 & 1.137 \\
D15.5 Group discussion forums & 100 & 3.84 & 1.070 \\
D15.6 Research information from online articles & 99 & 3.63 & 1.075 \\
\hline
\end{tabular}

TABLE 4: Descriptive statistics for the frequency of using smart devices to access sources of information.

\begin{tabular}{lccc}
\hline Item & $\begin{array}{c}\text { Number of } \\
\text { participants }\end{array}$ & Mean & $\begin{array}{c}\text { Standard } \\
\text { deviation }\end{array}$ \\
\hline D16.1 Blackboard & 99 & 3.74 & 1.103 \\
D16.2 Research articles & 98 & 3.39 & 1.145 \\
D16.3 Academic databases & 99 & 3.21 & 1.304 \\
D16.4 Google Scholar & 99 & 3.33 & 1.254 \\
D16.5 E-books & 99 & 2.98 & 1.278 \\
\hline
\end{tabular}


information from. Table 4 displays the descriptive statistics indicating the frequency of using smart devices to access the listed sources of information.

Blackboard, the educational management system used at the university, was rated the highest with a score of 3.74. E-books were rated the lowest with a score of 2.98. This means that most of the participants frequently used their smart devices to access Blackboard as the source of their coursework information as compared to other sources of information. The results from the questionnaire are corroborated in the interviews in Table 1, which highlight the importance of using smart devices to access sources of information such as electronic databases and Google Scholar.

As with other electronic devices, accessing information on smart devices exposes students to certain challenges related to the usability of the devices, limitations of the devices and harmful applications. Participants were prompted to indicate any challenges that they came across while using their smart devices to access and share coursework information.

\section{Challenges that students come across while accessing and sharing coursework information}

Participants were provided with a list of possible challenges that they might come across while accessing and sharing coursework information on their smart devices. Table 5 displays the descriptive statistics indicating the challenges students come across while accessing coursework information on their smart devices.

From the literature there are challenges that affect students while using their smart devices. For the purpose of this study, a selection of applicable challenges was made, and participants were asked to indicate which of the challenges were applicable to them while using their smart devices to access and share coursework information. Participants rated the challenge associated with the device not displaying certain documents properly the highest, with a score of 3.50 . The challenge of typing on the keypad was rated the lowest, with a score of 2.58 .

It is evident that the technical challenges such as difficulty in navigating through the menu, struggling to use a small touch screen and challenges in typing on the keypad have received the lowest ratings. This means that participants

TABLE 5: Descriptive statistics for challenges in the usage of smart devices.

\begin{tabular}{lccc}
\hline Item & $\begin{array}{c}\text { Number of } \\
\text { participants }\end{array}$ & Mean & $\begin{array}{c}\text { Standard } \\
\text { deviation }\end{array}$ \\
\hline D17.1 Difficulty in navigating through the menu & 100 & 2.65 & 1.175 \\
D17.2 Struggling to use a small touch screen & 100 & 2.69 & 1.263 \\
D17.3 Challenge in typing on the keypad & 100 & 2.58 & 1.290 \\
D17.4 Short battery life on the device & 100 & 3.46 & 1.331 \\
$\begin{array}{l}\text { D17.5 Device not displaying certain documents } \\
\text { properly }\end{array}$ & 100 & 3.50 & 1.262 \\
$\begin{array}{l}\text { D17.6 Unable to create or save documents } \\
\text { D17.7 Leaking of personal or private information }\end{array}$ & 100 & 3.31 & 1.228 \\
$\begin{array}{l}\text { D17.8 Viruses, worms and other harmful } \\
\text { applications hidden in websites }\end{array}$ & 99 & 2.62 & 1.028 \\
\hline
\end{tabular}

did not view them as seriously impacting on their information access and sharing activities. However, they remain challenges to some students' information access and sharing activities. As shown in Table 5, the last two items leaking of personal or private information and viruses, worms and other harmful applications hidden in websites - also received lower scores.

This section analysed the coursework information accessed by students on their smart devices, the frequency of using their smart devices to access coursework information and sources of information. The study also identified challenges that students come across while accessing and sharing coursework information. The results and findings are further discussed in the next section.

\section{Discussion}

The questionnaire results were corroborated by the interview results, where participants highlighted their views and opinions on the information they accessed using their smart devices. Although the results of the questionnaire were analysed statistically and the interview analysis was thematic, the results overall indicate that students use their smart devices to access module announcements. The interview results confirmed the initial results obtained from the questionnaire. The results show that students access a range of information on their smart devices, with the module announcements scoring the highest as compared to other information that was listed in Question D12 of the questionnaire. The results from the interview participants also indicate that students are likely to access module announcements on their smart devices.

With the frequency of sharing information, the results from D15 (the frequency of sharing information on study material) indicated that information such as bibliographic references, group discussion notes, online articles and book lists is accessed and shared frequently by participants. The results of D16 (smart device usage in accessing sources of information) indicate the frequency of smart device usage to access sources of information such as Blackboard, academic databases and Google Scholar. The usage of smart devices for accessing sources of information was also established from the interviews.

The results from D17 indicate that smart device usability and specifications posed challenges for students while accessing and sharing coursework information. Other challenges such as leaking of personal information and harmful applications received lower scores. This could indicate that perhaps students had taken precautions in ensuring the safety of their devices or that they had not yet come across such challenges.

Having discussed and evaluated the coursework information accessed and shared by MCom students on their smart devices, the next section provides recommendations and suggestions for future studies. 


\section{Recommendations and future studies}

Future research can be conducted with a larger sample size to obtain an in-depth analysis of the usage of smart devices for information access and sharing activities. The current study only focused on MCom students registered for coursework and excluded students who were enrolled for full dissertation MCom programmes. With an increase in the sample size, perhaps future studies can identify developing trends in the use of smart devices by postgraduate students. Considering that the study was conducted at one academic department at one university, further studies with comparative analysis in other departments and other institutions could be more meaningful towards assisting HEIs to establish effective applications that will support the information access and usage patterns of students within this rapidly changing environment.

\section{Conclusion}

The main aim of this article was to report on the coursework information accessed and shared by postgraduate students on smart devices. This study has shown that smart devices continue to play a crucial role in accessing and sharing information such as class notes, handouts, bibliographic references and information from articles. As revealed in the study, students use their smart devices to access specific information related to their coursework. The sources of information and the frequency of using smart devices to access the sources of information were discussed. In terms of the challenges, there are technical challenges such as small touch screen and inability to create or save documents that the tertiary institutions will not be able to resolve. However, with regard to other challenges such as documents not displaying properly, institutions can ensure that their VLEs are compatible with the smart device technology so that students can access them with ease.

The knowledge of the type of information accessed and shared by students, the frequency of sharing such information, the frequency of using smart devices to access various sources of information and the challenges in accessing information can assist tertiary institutions to incorporate educational technologies and improved VLEs that are compatible with the evolvement of smart devices. This will enhance the gathering and sharing of information for students as they use their smart devices for accessing and sharing information related to their coursework. Furthermore, the institutions will be able to stay abreast of any technological changes while offering students a platform characterised by quality and flexibility to access, process and share information. Smart devices enable easy access to course-related material, anywhere, anytime.

Having shown the contributions of this study, there are limitations. One of the limitations of this research is the limited scope and boundaries pertaining to the study having been conducted at one academic department of one university. The response rate for this study was small at
$35.5 \%$, and therefore the study could have provided in-depth findings if the response rate were higher. The other limitation relates to the interview scheduling. The availability of participants for interviews posed a challenge, as most of the students were studying part-time while working full-time. It was therefore difficult for them to volunteer to participate in the interview. The study focused only on students with smart devices. The findings and results are not necessarily applicable to the broader population of students at other universities.

\section{Acknowledgements}

The authors acknowledge the time and participation of the participants in the research.

\section{Competing interests}

The authors declare that they have no financial or personal relationships that may have inappropriately influenced them in writing this article.

\section{Authors' contribution}

E.J.D. undertook the study as a Master of Philosophy in Information Management degree; the dissertation was submitted to the Faculty of Management, University of Johannesburg, with M.A.M. as her supervisor. E.J.D.'s role included identifying the topic; designing, validating and administering the questionnaire data collection instrument; and performing data analyses for the purposes of the dissertation. M.A.M. reviewed several drafts of the dissertation and performed additional data analyses, interpretations and discussion in preparation for journal publication.

\section{References}

Balakrishnan, V. \& Loo, H.S., 2012, 'Mobile phone and short message service appropriation, usage and behavioural issues among university students', Journal of Social Sciences 8(3), 364-371. https://doi.org/10.3844/jssp.2012.364.371

Cummings, J., Merrill, A. \& Borrelli, S., 2010, 'The use of handheld mobile devices: Their impact and implications for library services', Library Hi Tech 28(1), 22-40. https://doi.org/10.1108/07378831011026670

Dresselhaus, A. \& Shrode, F., 2012, 'Mobile technologies and academics: Do students use mobile technologies in their academic lives and are librarians ready to meet this challenge?', Information Technology and Libraries 31(2), 82-101. https://doi. org/10.6017/ital.v31i2.2166

García-Peñalvo, F.J. \& Conde, M.A., 2015, 'The impact of a mobile personal learning environment in different educational contexts', Universal Access in the Information Society 14 (3), 375-387. https://doi.org/10.1007/s10209-014-0366-z

Gikas, J. \& Grant, M., 2013, 'Mobile computing devices in higher education: Student perspectives on learning with cellphones, smartphones and social media', Internet and Higher Education 19, 18-26. https://doi.org/10.1016/j.ineduc.2013.06.002

Hlodan, O., 2010, 'Mobile learning anytime, anywhere', BioScience 60(9), 682-683. https://doi.org/10.1525/bio.2010.60.9.4

Idrus, R. \& Ismail, I., 2010, 'Role of institutions of higher learning towards a knowledgebased community utilising mobile devices', Procedia Social and Behaviora Sciences 2, 2766-2770. https://doi.org/10.1016/j.sbspro.2010.03.412

Kafyulilo, A., 2014, 'Access, use and perceptions of teachers and students towards mobile phones as a tool for teaching and learning in Tanzania', Education and Information Technologies 19(1), 115-127. https://doi.org/10.1007/s10639-0129207-y

Keengwe, J. \& Bhargava, M., 2013, 'Mobile learning and integration of mobile technologies in education', Education and Information Technologies 19(4), 737-746. https://doi.org/10.1007/s10639-013-9250-3

Krogstie, M.A.J., 2011, 'Mobile student information system', Campus-Wide Information Systems 28(1), 5-15. https://doi.org/10.1108/10650741111097269 
Magnuson, M.L., 2013, 'Web 2.0 and information literacy instruction: Aligning technology with ACRL standards', The Journal of Academic Librarianship 39, 244-251. https://doi.org/10.1016/j.acalib.2013.01.008

Mang, C.F. \& Wardley, L.J., 2012, 'Effective adoption of tablets in post-secondary education: Recommendations based on a trial of iPads in university classes', Journal of Information Technology Education: Innovations in Practice 11(1), 301-317. https://doi.org/10.28945/1720

Manuguerra, M. \& Petocz, P., 2011, 'Promoting student engagement by integrating new technology into tertiary education: The role of the iPad', Asian Social Science 7(11), 61-65. https://doi.org/10.5539/ass.v7n11p61

Mayisela, T., 2013, 'The potential use of mobile technology: enhancing accessibility and communication in a blended learning course', South African Journal of Education 33(1), 1-18. https://doi.org/10.15700/saje.v33n1a629

Menkhoff, T. \& Bengtsson, M.L., 2012, 'Engaging students in higher education through mobile learning: Lessons learnt in a Chinese entrepreneurship course', Educational Research for Policy and Practice 11(3), 225-242. https://doi.org/10.1007/s10671 011-9123-8

Parsons, G., 2010, 'Information provision for HE distance learners using mobile devices', The Electronic Library 28(2), 231-244. https://doi.org/10.1108/ 02640471011033594

Rellinger, B.A., 2014, 'The diffusion of smartphones and tablets in higher education: A comparison of faculty and student perceptions and uses', Doctoral dissertation, Graduate College of Bowling Green State University, United States.
Roux, B. \& Falgoust, M., 2013, Information ethics in the context of smart devices, viewed 18 July 2013, from http://www.academia.edu/3493778/Information Ethics_in_the_Context_of_Smart_Devices.

Sheng, H., Siau, K. \& Nah, F., 2010, 'Understanding the values of mobile technology in education: A value-focused thinking approach', The Data Base for Advances in Information Systems 41(2), 25-44. https://doi.org/10.1145/1795377. 1795380

Shin, D.H., 2012, 'Cross-analysis of usability and aesthetic in smart devices: What influences users' preferences?', Cross Cultural Management 19(4), 563-587. https://doi.org/10.1108/13527601211270020

Suki, N.M., 2013 'Students' dependence on smart phones: The influence of socia needs, social influences and convenience', Campus-Wide Information Systems 30(2), 124-134. https://doi.org/10.1108/10650741311306309

Taleb, Z. \& Sohrabi, A., 2012, 'Learning on the move: The use of mobile technology to support learning for university students', Procedia-Social and Behavioral Sciences 69, 1102-1109. https://doi.org/10.1016/j.sbspro.2012.12.038

Ting, D.H. Lim, S.F, Patanmacia, T.L., Low, C.G. \& Ker, G.C, 2011, 'Dependency on smartphone and the impact on purchase behaviour', Young Consumers 12(3), 193-203. https://doi.org/10.1108/17473611111163250

Whittaker, S. \& Dunham, J., 2009, 'Experimenting with Web 2.0 to cultivate information literacy within a medical ethics, law and human rights course', Journal of Information Literacy 3(1), 51-59. https://doi.org/10.11645/3.1.213 


\section{Appendix 1: \\ Research questionnaire: Letter of informed consent}

Dear Participant:

My name is Eli Dhlamini, currently enrolled for my Master of Philosophy (MPhil) in Information Management at the University of Johannesburg. I am completing my dissertation as part of the fulfilment of my master's degree.

You are invited to participate in a research project entitled 'Smart device usage in facilitating information gathering and sharing'. The purpose of this survey is to establish how smart devices can facilitate information gathering and sharing for tertiary students.

Your participation in this survey is confidential and voluntary. You may withdraw from participating in this study at any stage. You will receive no compensation for participating in the research study. Responses to the survey will only be reported in aggregated form to protect the identity of participants.

Kindly complete and submit the questionnaire online on or before 15 July 2016.

Further information regarding the research including the results can be obtained from the principal researcher, Eli Dhlamini or my supervisor, Prof. Martie Mearns (contact details provided to research participants, but hidden in publication for the protection against unsolicited contacts).

Thank you for your consideration. Your assistance is greatly appreciated.

[Your signature below indicates that you have read the above information and agreed to participate in the research study on smart device usage in facilitating information gathering and sharing]. Your details will be kept confidential.

Printed Name

Signature 
The questionnaire explores the usage of smart devices for academic purposes. For the purpose of this questionnaire, the smart devices refer to smartphones or tablets.

Please answer the following questions by crossing $(\mathrm{X})$ the relevant block or writing your answer in the space provided.

\section{Part A: Background information}

This section of the questionnaire refers to the background information that will be used for group comparison. All responses will remain anonymous. Your co-operation is appreciated.

1. Gender:

\begin{tabular}{|c|c|}
\hline Male & 1 \\
\hline Female & 2 \\
\hline
\end{tabular}

2. Age (in complete years):

3. What is your primary smart device?

\begin{tabular}{|c|c|}
\hline Tablet & 1 \\
\hline Smartphone & 2 \\
\hline
\end{tabular}

4. Why have you chosen this smart device as your primary device?

\begin{tabular}{|c|c|}
\hline Affordable & 1 \\
\hline Ease of use & 2 \\
\hline Flexible & 3 \\
\hline Other: specify & 4 \\
\hline
\end{tabular}

5. Smart device usage experience:

\begin{tabular}{|c|c|}
\hline Less than 1 year & 1 \\
\hline $1-2$ years & 2 \\
\hline $2-5$ years & 3 \\
\hline More than 5 years & 4 \\
\hline
\end{tabular}

\section{Part B: Adoption profile}

This section explores your smart device adoption profile.

6. Which of the following describes you in terms of smart device adoption? (mark one option only):

\begin{tabular}{|c|c|c|c|}
\hline a. & Before the popularity of smart devices, I felt interested in using a smart device and tried to figure out the different functions. & 1 \\
\hline b. & I made the decision to use a smart device on the basis of my intuition. In my view, a smart device is a useful device and I began to use a smart device in the early stages. & 2 \\
\hline c. & $\begin{array}{l}\text { I first hesitated to use a smart device because of doubts about whether it will become popular. I made the decision after I realised that smart devices are now } \\
\text { completely developed. }\end{array}$ & 3 \\
\hline d. & I knew that smart devices will become popular, but I only decided to use one only after its specifications and service support were well established. & 4 \\
\hline e. & Even though a smart device is popular I seldom use its full functionality or capabilities. & 5 \\
\hline
\end{tabular}

\section{Part C: Reasons for using a smart device}

This section of the questionnaire examines your perception regarding smart device usage for information sharing activities. Answer the following questions with regard to your primary device. 
Relative advantage:

7. To what extent do you agree with each of the following statements in terms of the advantage of using your smart device? Indicate your answer using the following 5-point scale where:

- 1 = Strongly agree

- 2 = Disagree

- $3=$ Neutral

- $4=$ Agree

- 5 = Strongly Agree

Number Relative advantage of using a smart device

\begin{tabular}{ccccc}
\multicolumn{5}{c}{ Answer } \\
\hline $\begin{array}{c}\text { Strongly } \\
\text { disagree }\end{array}$ & Disagree & Neutral & Agree & $\begin{array}{c}\text { Strongly } \\
\text { agree }\end{array}$ \\
\hline 1 & 2 & 3 & 4 & 5 \\
1 & 2 & 3 & 4 & 5 \\
1 & 2 & 3 & 4 & 5 \\
1 & 2 & 3 & 4 & 5 \\
1 & 2 & 3 & 4 & 5 \\
1 & 2 & 3 & 4 & 5 \\
\hline
\end{tabular}

8. To what extent do you agree with each of the following statements in terms of how well-suited your smart device is to your coursework activities?

\begin{tabular}{|c|c|c|c|c|c|c|}
\hline \multirow[t]{2}{*}{ Number } & \multirow[t]{2}{*}{ Suitability of a smart device to your coursework activities } & \multicolumn{5}{|c|}{ Answer } \\
\hline & & $\begin{array}{l}\text { Strongly } \\
\text { disagree }\end{array}$ & Disagree & Neutral & Agree & $\begin{array}{c}\text { Strongly } \\
\text { agree }\end{array}$ \\
\hline a. & Browsing the Internet using my smart device while I am on campus enhances my learning goals. & 1 & 2 & 3 & 4 & 5 \\
\hline b. & $\begin{array}{l}\text { Using smartphones/tablets for sharing academic information with other students is compatible with my } \\
\text { learning needs. }\end{array}$ & 1 & 2 & 3 & 4 & 5 \\
\hline c. & It is easier to do my coursework using my smart device. & 1 & 2 & 3 & 4 & 5 \\
\hline d. & $\begin{array}{l}\text { My smartphone/tablet enables me to edit documents and multimedia files that I send to or receive from } \\
\text { other students for academic purposes. }\end{array}$ & 1 & 2 & 3 & 4 & 5 \\
\hline e. & Overall it is more beneficial for me to use my smart device as it fits in with my academic information needs. & 1 & 2 & 3 & 4 & 5 \\
\hline
\end{tabular}

9. To what extent do you agree with each of the following statements in terms of the ease of use of your smart device?

\begin{tabular}{|c|c|c|c|c|c|c|}
\hline \multirow[t]{2}{*}{ Number } & \multirow[t]{2}{*}{ Smart device ease of use } & \multicolumn{5}{|c|}{ Answer } \\
\hline & & $\begin{array}{l}\text { Strongly } \\
\text { disagree }\end{array}$ & Disagree & Neutral & Agree & $\begin{array}{l}\text { Strongly } \\
\text { agree }\end{array}$ \\
\hline a. & Using my smartphone/tablet to access information for my coursework has been easy for me. & 1 & 2 & 3 & 4 & 5 \\
\hline b. & Sharing notes and class slides on my smartphone/tablet has been easy for me. & 1 & 2 & 3 & 4 & 5 \\
\hline c. & I can easily complete my academic assignments using my smartphone/tablet. & 1 & 2 & 3 & 4 & 5 \\
\hline d. & $\begin{array}{l}\text { I find it easy to navigate through different menu features on my smartphone/tablet to search for coursework } \\
\text { information. }\end{array}$ & 1 & 2 & 3 & 4 & 5 \\
\hline
\end{tabular}

10. To what extent do you agree with each of the following statements in terms of trying out different features of your smart device?

\begin{tabular}{|c|c|c|c|c|c|c|}
\hline \multirow[t]{2}{*}{ Number } & \multirow[t]{2}{*}{ Trialability: Of features on smart devices } & \multicolumn{5}{|c|}{ Answer } \\
\hline & & $\begin{array}{l}\text { Strongly } \\
\text { disagree }\end{array}$ & Disagree & Neutral & Agree & $\begin{array}{c}\text { Strongly } \\
\text { agree }\end{array}$ \\
\hline a. & $\begin{array}{l}\text { I had an adequate number of opportunities to try various features of my smartphone/tablet to search for } \\
\text { information for my coursework. }\end{array}$ & 1 & 2 & 3 & 4 & 5 \\
\hline b. & $\begin{array}{l}\text { I was able to try out individual features of smartphones/tablets at my own pace to complete coursework } \\
\text { tasks. }\end{array}$ & 1 & 2 & 3 & 4 & 5 \\
\hline c. & $\begin{array}{l}\text { I had an opportunity to try out various social media applications on my smartphone/tablet to engage in } \\
\text { group discussions for academic purposes. }\end{array}$ & 1 & 2 & 3 & 4 & 5 \\
\hline d. & $\begin{array}{l}\text { I was able to try smartphones/tablets with fewer information searches relating to my coursework before } \\
\text { deciding to use it for all of my academic information searching and sharing activities. }\end{array}$ & 1 & 2 & 3 & 4 & 5 \\
\hline e. & $\begin{array}{l}\text { I was able to try out various applications on my smartphone/tablet for sharing coursework information with } \\
\text { other students. }\end{array}$ & 1 & 2 & 3 & 4 & 5 \\
\hline
\end{tabular}


11. To what extent do you agree with each of the following statements in terms of observing how other people use their smart devices in terms of gathering and sharing information?

\begin{tabular}{|c|c|c|c|c|c|c|}
\hline \multirow[t]{2}{*}{ Number } & \multirow[t]{2}{*}{ Observability: Observing how other people use smart devices for gathering and sharing information } & \multicolumn{5}{|c|}{ Answer } \\
\hline & & $\begin{array}{l}\text { Strongly } \\
\text { disagree }\end{array}$ & Disagree & Neutral & Agree & $\begin{array}{l}\text { Strongly } \\
\text { agree }\end{array}$ \\
\hline a. & $\begin{array}{l}\text { I have observed how other students use their smartphones/tablets for gathering or sharing information for } \\
\text { academic purposes. }\end{array}$ & 1 & 2 & 3 & 4 & 5 \\
\hline b. & Many of the students that I know use their smartphones/tablets to perform different coursework activities. & 1 & 2 & 3 & 4 & 5 \\
\hline c. & I have observed how my classmates or friends use their smartphones/tablets for sharing coursework material. & 1 & 2 & 3 & 4 & 5 \\
\hline d. & $\begin{array}{l}\text { I have observed examples of best practices from people I know in the use of smartphones/tablets for } \\
\text { academic purposes. }\end{array}$ & 1 & 2 & 3 & 4 & 5 \\
\hline e. & $\begin{array}{l}\text { In general I had a lot of opportunities to see people around me using a smartphone/tablet for accessing and } \\
\text { sharing information for coursework activities. }\end{array}$ & 1 & 2 & 3 & 4 & 5 \\
\hline
\end{tabular}

\section{Part D: This section of the questionnaire explores the information activities on your smart devices}

12. How often do you use a smart device for accessing and sharing the following coursework information?

\begin{tabular}{|c|c|c|c|c|c|c|}
\hline \multirow[t]{2}{*}{ Number } & \multirow[t]{2}{*}{ Smart device usage and information activities } & \multicolumn{5}{|c|}{ Answer } \\
\hline & & Never & Rarely & Sometimes & Often & Always \\
\hline a. & Accessing and reading announcements & 1 & 2 & 3 & 4 & 5 \\
\hline b. & Accessing course assignments & 1 & 2 & 3 & 4 & 5 \\
\hline c. & Sharing handouts, lectures, articles & 1 & 2 & 3 & 4 & 5 \\
\hline d. & Retrieving coursework images from other students & 1 & 2 & 3 & 4 & 5 \\
\hline e. & Sharing notes with other students & 1 & 2 & 3 & 4 & 5 \\
\hline f. & Sharing ideas with other students via group discussions & 1 & 2 & 3 & 4 & 5 \\
\hline g. & Sharing additional learning material & 1 & 2 & 3 & 4 & 5 \\
\hline
\end{tabular}

13. Do you belong to any specific academic group related to your coursework?

\begin{tabular}{|c|c|}
\hline Yes & 1 \\
\hline No & 2 \\
\hline $\begin{array}{c}\text { Please indicate reasons for } \\
\text { your choice above. }\end{array}$ & 3 \\
\hline
\end{tabular}

14. How effective is each of the following social media platforms for the MCom office in sharing coursework information with students.

\begin{tabular}{|c|c|c|c|c|c|c|}
\hline \multirow[t]{2}{*}{ Number } & \multirow[t]{2}{*}{ Social media platform } & \multicolumn{5}{|c|}{ Answer } \\
\hline & & Not effective at all & Somewhat not effective & Neutral & Effective & Very effective \\
\hline a. & WhatsApp & 1 & 2 & 3 & 4 & 5 \\
\hline b. & BBM & 1 & 2 & 3 & 4 & 5 \\
\hline c. & Mixit & 1 & 2 & 3 & 4 & 5 \\
\hline d. & Dropbox & 1 & 2 & 3 & 4 & 5 \\
\hline e. & Facebook & 1 & 2 & 3 & 4 & 5 \\
\hline f. & Twitter & 1 & 2 & 3 & 4 & 5 \\
\hline g. & MySpace & 1 & 2 & 3 & 4 & 5 \\
\hline h. & Other (please specify) & 1 & 2 & 3 & 4 & 5 \\
\hline
\end{tabular}

15. How often do you share the following information on your studies?

\begin{tabular}{llcccc}
\hline Number & Question & & & Answer \\
\cline { 3 - 5 } & & Never & Rarely & Sometimes & Always \\
\hline a. & Book lists & 1 & 2 & 3 & 3 \\
b. & Bibliographic reference lists & 1 & 2 & 3 & 3 \\
c. & Notes & 1 & 2 & 3 & 3 \\
d. & Class timetable & 1 & 2 & 3 & 4 \\
e. & Group discussions & 1 & 2 & 3 & 4 \\
f. & Research information from & 1 & 2 & 5 \\
\hline
\end{tabular}


16. How often do you use your smart device to access the following sources of information for your coursework?

\begin{tabular}{|c|c|c|c|c|c|c|}
\hline \multirow[t]{2}{*}{ Number } & \multirow[t]{2}{*}{ Question } & \multicolumn{5}{|c|}{ Answer } \\
\hline & & Never & Rarely & Sometimes & Often & Always \\
\hline a. & Blackboard & 1 & 2 & 3 & 4 & 5 \\
\hline b. & Research articles & 1 & 2 & 3 & 4 & 5 \\
\hline c. & Academic databases & 1 & 2 & 3 & 4 & 5 \\
\hline d. & Google Scholar & 1 & 2 & 3 & 4 & 5 \\
\hline e. & E-books & 1 & 2 & 3 & 4 & 5 \\
\hline
\end{tabular}

17. How likely are you to experience the following in the usage of your smart device?

\begin{tabular}{|c|c|c|c|c|c|c|}
\hline \multirow[t]{2}{*}{ Number } & \multirow[t]{2}{*}{ Question } & \multicolumn{5}{|c|}{ Answer } \\
\hline & & Very unlikely & Unlikely & Neutral & Likely & Very likely \\
\hline a. & Difficulty in navigating through the menu & 1 & 2 & 3 & 4 & 5 \\
\hline b. & Struggling to use a small touch screen & 1 & 2 & 3 & 4 & 5 \\
\hline c. & Challenge in typing on the keypad & 1 & 2 & 3 & 4 & 5 \\
\hline d. & Short battery life on the device & 1 & 2 & 3 & 4 & 5 \\
\hline e. & Device not displaying certain documents properly & 1 & 2 & 3 & 4 & 5 \\
\hline g. & Leaking of personal or private information & 1 & 2 & 3 & 4 & 5 \\
\hline h. & $\begin{array}{l}\text { Viruses, worms and other harmful applications } \\
\text { hidden in websites }\end{array}$ & 1 & 2 & 3 & 4 & 5 \\
\hline
\end{tabular}

\section{Part E: This section examines your perception regarding the role of a smart device in relation to your coursework.}

18. To what extent do you agree with each of the following statements regarding the role of your smart device?

\begin{tabular}{|c|c|c|c|c|c|c|}
\hline \multirow[t]{2}{*}{ Number } & \multirow[t]{2}{*}{ Question } & \multicolumn{5}{|c|}{ Answer } \\
\hline & & Extremely unlikely & Unlikely & Neutral & Likely & Very likely \\
\hline a. & $\begin{array}{l}\text { My smart device allows me to engage in multiple } \\
\text { academic information searches at the same time. }\end{array}$ & 1 & 2 & 3 & 4 & 5 \\
\hline b. & $\begin{array}{l}\text { My smart device allows me to access coursework } \\
\text { information faster. }\end{array}$ & 1 & 2 & 3 & 4 & 5 \\
\hline c. & $\begin{array}{l}\text { My smart device enables me to share coursework } \\
\text { information with other people anytime. }\end{array}$ & 1 & 2 & 3 & 4 & 5 \\
\hline d. & My smart device makes my studies easier. & 1 & 2 & 3 & 4 & 5 \\
\hline e. & $\begin{array}{l}\text { My smart device allows me more freedom as I can } \\
\text { use it anywhere anytime for academic purposes. }\end{array}$ & 1 & 2 & 3 & 4 & 5 \\
\hline
\end{tabular}

Thank you for your assistance in completing this questionnaire. 


\section{Appendix 2: \\ Interview questions: Letter Of Informed Consent}

\section{Dear Participant:}

My name is Eli Dhlamini, currently enrolled for my Master of Philosophy in Information Management at the University of Johannesburg. I am completing my dissertation as part of the fulfilment of my masters' degree.

You are invited to participate in a research project entitled 'Smart device usage in facilitating information gathering and sharing'. The purpose of this survey is to establish how smart devices can facilitate information gathering and sharing for tertiary students. Part of the research involves interviewing students who use their smart devices for coursework activities, and for this reason, I would like to invite you to take part in the interview. The interview will take about $20 \mathrm{~min}$. With your permission, I would like to record the interview and take notes for later analysis. The data will be kept secure and destroyed after the completion of the project. Your participation in this interview is confidential and voluntary. You may withdraw from participating in this study at any stage. You will receive no compensation for participating in the research study. Responses to the interview will only be reported in aggregated form to protect the identity of participants.

Further information regarding the research including the results can be obtained from the principal researcher, Eli Dhlamini, or my supervisor, Prof. Martie Mearns (contact details provided to research participants, but hidden in publication for the protection against unsolicited contacts).

Thank you for your consideration. Your assistance is greatly appreciated.

[Your signature below indicates that you have read the above information and agreed to participate in the research study]. Your details will be kept confidential.

Printed Name

Signature

Date 
This research focuses on mixed-method research using both quantitative and qualitative approaches. The first phase involved collecting data quantitatively using questionnaires. The preliminary findings from the questionnaires revealed the following:

a. Students use their smart devices for accessing and sharing coursework information.

b. Smart devices are less complex and the results of using them are observable.

c. Students had opportunities to try out unique features and searches for coursework purposes.

d. Students access and share information such as announcements, handouts, lecture notes and articles.

e. Various sources such as Blackboard, academic databases and Google Scholar are used to access information.

f. Smart devices allow flexibility to be carried around and the ability to perform multiple information searches as well as quicker access to coursework information.

g. Advancing academic groups through social media platforms such as Dropbox and WhatsApp can improve accessing and sharing of information for students.

h. The MCom office and the university can ensure that they use social media platforms to connect with students, share information and promote student work.

The interviews form part of the second phase of qualitative data collection. The purpose of this interview is to investigate possible improvements that the MCom office can implement to facilitate the students' access and information sharing practices.

\section{Questions}

1. What kind of information did you access using your smart device while studying towards your MCom?

1.1 Why did you use your smart device to access this information?

2. Do you think you are getting/were getting enough support from the MCom office in terms of sharing information? Please elaborate.

3. How would you suggest the MCom office use fast moving trends in the smart device technology to their advantage to support students' information activities?

4. Do you think the MCom office should encourage smart device usage for coursework? If yes, what support do you think the MCom office can provide to assist students to improve smart device usage for coursework?

5. [If groups did not yet surface in the discussion, ask the following] Many students found belonging to some sort of academic group was beneficial in their studies. Did you belong to a group?

5.1 If yes, which platform did you use for the group?

5.2 What benefits did you gain from the group?

5.3 If no, why did you not join in a group or create a group?

5.4 In hindsight, how do you think a group could have supported your studies?

6. One of the findings from the questionnaire was that 'the MCom office and the university can ensure that they use social media platforms to connect with students, share information and promote student work'.

6.1 Do you agree/disagree with this comment? If agreed, which social media platforms would you prefer and for sharing what kind of information?

6.2 If disagreed, why do you not think that social media should be used?

7. Any other comments you would like to add. 